\title{
Estimation of economic wellbeing at falling price per barrel of oil
}

\author{
Anna B. Zhdanova \\ Department of Management \\ National Research Tomsk Polytechnic University \\ Tomsk, Russia \\ zhdanova_ab@mail.ru \\ Kristina A. Bannova \\ Department of Management \\ National Research Tomsk Polytechnic University \\ Tomsk, Russia \\ bannovaka@yandex.ru
}

\author{
Irina N. Dolgikh \\ Department of Management \\ National Research Tomsk Polytechnic University \\ Tomsk, Russia \\ Kseniya Kamenskaya \\ Department of Management \\ National Research Tomsk Polytechnic University \\ Tomsk, Russia \\ Natalia V. Pokrovskaia \\ Department of Credit Theory and Financial Management \\ Saint-Petersburg State University \\ Saint Petersburg, Russia
}

\begin{abstract}
Forecasts of economic growth in recent years are often revised for the worse. Not only in Russia but also in the global economy. Economic growth has stimulated the consumption of energy resources, including oil and therefore reduction in forecasts of economic growth have a negative impact on the oil market. For many commodities the dollar is important. With the growth of dollar commodity prices are beginning to fall in price, and vice versa. The growth of the dollar and oil volumes in the market led to a decline in oil prices. The Russian budget, almost half of which depends on oil prices, can not respond to this movement, as a result - another decline of the ruble. In this article the author considers the question of a mathematical correlation between the external factor - the change in the value of oil and refining the assessment of well-being of international corporations
\end{abstract}

Keywords-oil; company; economic wellbeing; factors; effectiveness.

\section{INTRODUCTION}

The development of large corporations is an important element in the general system-an economic system, development and success of a change that affects the wellbeing of not only the employees of the corporations themselves, but also residents of the regions in which business is conducted. The changes in macroeconomic factors have a significant impact on the welfare and growth prospects of the companies, it is important to anticipate this impact and plan corrective actions. 
management. From the standpoint of the concept of cost management, the company - it is a business enterprise that generates revenues from the tangible and intangible assets. The problem of valuations at the current stage of development has touched many Russian companies. Almost all large and medium-sized mining companies have entered the market of securities in the foreign and domestic markets. The cost of Russian oil and gas companies with tens of billions of dollars.

Getting to the valuation of companies, it is necessary to determine what kind of index value will be discussed. Evaluation methods of company value and cash flows generated by a number of stages in its development. Initially, the calculations were performed using the torque multipliers and interval, margins, that the conditions of their divergent values are not allowed in general to get a reliable answer about the value of the company. The next step is the valuation was carried out based on the evaluation values for earnings from the financial statements: operating profit before interest and tax (EBIT - Earnings before Interest and Taxes), the profit before interest, taxes, depreciation and amortization (EBITDA - Earnings before Interest, taxes, Depreciation and Amortization), net operating income, net of taxes adjusted (NOPLAT - net operating profit Less adjusted tax) and net operating income before interest expense (NOPAT - net operating profit After tax). At a time when in many countries reporting is based on national standards and IFRS standards in full are not used in full, the results are difficult to compare and estimate the cost becomes accurate. Among the existing traditional approaches to the assessment of the company's value for the investigation of EPS figure was chosen. There are some approaches to an estimation value of the company from which the indicator has been selected EPS.

Earnings per share (EPS) - is one of the main financial indicators, which is used to assess the effectiveness of the company. EPS is one of the few financial indicators, calculation rules which are fixed in a number of accounting standards (IAS 33, GAAP). The formula of

its calculation the following (1):

EPS=(Net income-Preferred Dividends)/Average number (1)

This coefficient shows how much rubles of net profit due to one common share put into circulation. The increase EPS undoubtedly a positive sign, which evidence of the improvement the financial results of the company.

In this study, an analysis of quantitative indicators of Russian oil and gas companies in the period from 2008 and the calculation of the value of companies for one barrel of oil in order to detect stable correlation dependencies.

\section{ANALYSIS THE DYNAMICS OF CHANGES IN THE COST OF} OIL

The current energy system realizes a passive trIn the period from 2008, the history of the oil price can be a lot of interesting facts. The average value of a barrel of Brent presented in Table. 1.

TABLE I THE AVERAGE PRICE PER BARREL OF BRENT CRUDE OIL

\begin{tabular}{|c|c|}
\hline Analysis period & \$ per barrel \\
\hline 2008 г. & 97,7 \\
\hline 2009 г. & 61,9 \\
\hline 2010 г. & 79,6 \\
\hline 2011 г. & 111,0 \\
\hline 2012 г. & 121,4 \\
\hline 2013 г. & 108,8 \\
\hline 2014 г. & 98,9 \\
\hline
\end{tabular}

The next peak price reached 13 March 2012 (\$ 128.14), but because of the problems in the Eurozone and the political crisis in France and Greece once again began to fall. June 1, 2012 the price of oil fell to below \$ 100 (\$ 98.63), but was able to return to the level of $\$ 100-115$ in the second half of July: the growth affected by the crisis in Syria, a fire at the refinery in California, August 7, 2012 year and other current events. The annual average price in 2012 was $\$ 121.4$.

The first half of 2014 went down in history average price per barrel, but with the end of the summer there has been a decline in demand for fuel in the United States and China, against which there was excess supply due to high levels of oil production in the United States and imports from Saudi Arabia. Thus, 31 of December, 2014 quotes for Brent crude settled at $\$ 55.27$ a barrel, then fell below \$ 50, especially in the second half of July. This fact was caused by the crisis in the stock market in China, Iran plans to increase oil exports after the lifting of sanctions and the data that the US continues to put into operation new production capacity. 24 of August stock prices of Brent crude oil for the first time since March 2009 fell to levels below $\$ 45$ per barrel.

\section{DYNAMICS OF CHANGES IN THE VALUE OF COMPANIES}

Speaking about the oil and gas industry, we want to highlight just the enterprise, which is open to the outside world has a lot of value for the analysis and calculations. One of the largest in Russia should be made of "Gazprom oil", OAO "NK" Rosneft ", PJSC" LUKOIL ". Each of these companies occupies a significant place in the industry for the exploration and production of oil and gas, as well as the production of petroleum and petrochemical products and its marketing. Among the foreign companies will definitely stand the US Chevron Corporation, the Dutch-British Royal Dutch Shell, Saudi Aramco in Saudi Arabia. By the principle of availability of information for the analysis were selected Russian PAO "LUKOIL" and the US Chevron Corporation, which is one the largest oil and gas companies in the world. 
Comparative analysis of companies and their cost will be carried out in terms of EPS (earnings per share). These indicators EPS companies under consideration in the period since 2008 are summarized in the Table. 2 .

TABLE II INDICATORS EPS PJSC "LUKOIL" AND CHEVRON CORPORATION

\begin{tabular}{lcc}
\hline Period, Year & $\begin{array}{c}\text { Chevron Corporation, } \\
\text { EPS, } \mathbf{\$}\end{array}$ & $\begin{array}{c}\text { PAO } « \text { Lukoil», EPS, } \\
\text { rub. }\end{array}$ \\
\hline $\mathbf{2 0 0 8}$ & 11,74 & 270,67 \\
$\mathbf{2 0 0 9}$ & 5,26 & 262,82 \\
$\mathbf{2 0 1 0}$ & 9,53 & 332,68 \\
$\mathbf{2 0 1 1}$ & 13,54 & 391,04 \\
$\mathbf{2 0 1 2}$ & 13,42 & 449,61 \\
$\mathbf{2 0 1 3}$ & 11,18 & 330,80 \\
$\mathbf{2 0 1 4}$ & 10,21 & 242,87 \\
$\mathbf{2 0 1 5}$ & 6,46 & 318,72 \\
\hline
\end{tabular}

From the presented data show that earnings per share (EPS) in crisis and post-crisis time, both companies have been quite low. This indicates a deterioration in the financial results, including a significant reduction in net profit.

\section{ANALYSIS OF THE COMPANY'S VALUE CHANGES DEPENDING ON CHANGES IN THE COST OF OIL}

Analysis of the companies was carried out on the basis of the relationship between the search of a barrel of oil (Y) and the index EPS (X) in the same period. The main method of analysis was adopted by correlation analysis, designed to detect the relationship between several random variables. The dependence is expressed by a linear function (2):

$$
\mathrm{Y}^{\prime}=\mathrm{a}_{0}+\mathrm{a}_{1} \mathrm{x}
$$

Thus calculated values a0 and a1 possible through the following system of equations (3):

$$
\left\{\begin{array}{c}
n a_{0}+a_{1} \sum x=\Sigma y \\
a_{0} \Sigma x+a_{1} \Sigma x^{2}=\Sigma x y
\end{array}\right.
$$

Also during the correlation analysis it is no less important to calculate the index of closeness of the connection. Such is the indication will be the the coefficient of correlation, which should be calculated according to the formula (4):

$$
\mathbf{r}=\frac{\sum x y-\sum x+\frac{\sum y}{n}}{\sqrt{\sum x^{2}-\frac{\left(\sum x\right)^{\wedge} z}{n}}}
$$

All calculations associated with the analysis of the two companies are shown in Table. 3.

TABLE III CORRELATION ANALYSIS EPS DEPENDING ON OIL

\begin{tabular}{|c|c|c|c|c|c|c|}
\hline & & & & 9 & , 00 & 27 \\
\hline 2009 & 5,26 & 61,90 & 27,67 & $\begin{array}{c}3831,6 \\
1\end{array}$ & $\begin{array}{c}325, \\
59\end{array}$ & $\begin{array}{c}50,7 \\
9\end{array}$ \\
\hline 2010 & 9,53 & 79,60 & 90,82 & $\begin{array}{c}6336,1 \\
6\end{array}$ & $\begin{array}{c}758, \\
59\end{array}$ & $\begin{array}{c}85,3 \\
7\end{array}$ \\
\hline 2011 & 13,54 & 111,00 & 183,33 & $\begin{array}{c}12321, \\
00\end{array}$ & $\begin{array}{c}1502 \\
, 94 \\
\end{array}$ & $\begin{array}{c}117, \\
85\end{array}$ \\
\hline 2012 & 13,42 & 121,40 & 180,10 & $\begin{array}{c}14737, \\
96\end{array}$ & $\begin{array}{c}1629 \\
19\end{array}$ & $\begin{array}{c}116, \\
88\end{array}$ \\
\hline 2013 & 11,18 & 108,80 & 124,99 & $\begin{array}{c}11837 \\
44\end{array}$ & $\begin{array}{c}1216 \\
, 38\end{array}$ & $\begin{array}{c}98,7 \\
4\end{array}$ \\
\hline 2014 & 10,21 & 98,90 & 104,24 & $\begin{array}{c}9781,2 \\
1\end{array}$ & $\begin{array}{c}1009 \\
, 77\end{array}$ & $\begin{array}{c}90,8 \\
8\end{array}$ \\
\hline 2015 & 6,46 & 45,00 & 41,73 & $\begin{array}{c}2025,0 \\
0\end{array}$ & $\begin{array}{c}290, \\
70\end{array}$ & $\begin{array}{c}60,5 \\
1\end{array}$ \\
\hline Total & 81,34 & 724,30 & 890,71 & $\begin{array}{c}70415, \\
67 \\
\end{array}$ & $\begin{array}{c}7880 \\
, 16 \\
\end{array}$ & $\begin{array}{c}724, \\
30\end{array}$ \\
\hline \multicolumn{7}{|c|}{ PAO "Lukoil" } \\
\hline & $\begin{array}{l}\text { EPS, } \\
\text { rub. } \\
\text { per } \\
\text { share } \\
(X)\end{array}$ & $\begin{array}{l}\text { The } \\
\text { price } \\
\text { per } \\
\text { barrel, } \\
\text { rub. } \\
\text { (Y) }\end{array}$ & $\mathrm{X}^{2}$ & $\mathrm{Y}^{2}$ & $\mathrm{X} * \mathrm{Y}$ & $\mathrm{Y}^{\star}$ \\
\hline 2008 & 270,67 & $\begin{array}{c}2428,8 \\
2\end{array}$ & $\begin{array}{c}73262, \\
25\end{array}$ & $\begin{array}{c}589916 \\
6,59\end{array}$ & $\begin{array}{c}6574 \\
08,7 \\
1 \\
\end{array}$ & $\begin{array}{c}2793 \\
, 28 \\
\end{array}$ \\
\hline 2009 & 262,82 & $\begin{array}{c}1970,2 \\
8\end{array}$ & $\begin{array}{c}69074, \\
35\end{array}$ & $\begin{array}{c}388200 \\
3,28\end{array}$ & $\begin{array}{c}5178 \\
28,9 \\
9\end{array}$ & $\begin{array}{c}2760 \\
, 64\end{array}$ \\
\hline 2010 & 332,68 & $\begin{array}{c}2416,6 \\
6\end{array}$ & $\begin{array}{c}110675 \\
, 98\end{array}$ & $\begin{array}{c}584024 \\
5,56\end{array}$ & $\begin{array}{c}8039 \\
74,4 \\
5\end{array}$ & $\begin{array}{c}3051 \\
, 10\end{array}$ \\
\hline 2011 & 391,04 & $\begin{array}{c}3262,2 \\
9\end{array}$ & $\begin{array}{c}152912 \\
, 28\end{array}$ & $\begin{array}{c}106425 \\
36,04\end{array}$ & $\begin{array}{c}1275 \\
685, \\
88\end{array}$ & $\begin{array}{c}3293 \\
, 74\end{array}$ \\
\hline 2012 & 449,61 & $\begin{array}{c}3773,1 \\
1\end{array}$ & $\begin{array}{c}202149 \\
, 15\end{array}$ & $\begin{array}{c}142363 \\
59,07\end{array}$ & $\begin{array}{c}1696 \\
427, \\
99\end{array}$ & $\begin{array}{c}3537 \\
, 26 \\
\end{array}$ \\
\hline 2013 & 330,80 & $\begin{array}{c}3465,2 \\
8\end{array}$ & $\begin{array}{c}109428 \\
, 64\end{array}$ & $\begin{array}{c}120081 \\
65,48\end{array}$ & $\begin{array}{c}1146 \\
314, \\
62\end{array}$ & $\begin{array}{c}3043 \\
, 28 \\
\end{array}$ \\
\hline 2014 & 242,87 & $\begin{array}{c}3818,5 \\
3\end{array}$ & $\begin{array}{c}58985 \\
84\end{array}$ & $\begin{array}{c}145811 \\
71,36\end{array}$ & $\begin{array}{c}9274 \\
06,3 \\
8 \\
\end{array}$ & $\begin{array}{c}2677 \\
, 70 \\
\end{array}$ \\
\hline 2015 & 318,72 & $\begin{array}{c}3015,0 \\
0\end{array}$ & $\begin{array}{c}101582 \\
, 44\end{array}$ & $\begin{array}{c}909022 \\
5,00\end{array}$ & $\begin{array}{c}9609 \\
40,8 \\
0\end{array}$ & $\begin{array}{c}2993 \\
, 06\end{array}$ \\
\hline Total & $\begin{array}{c}2599,2 \\
1\end{array}$ & $\begin{array}{c}24149 \\
97\end{array}$ & $\begin{array}{c}878070 \\
, 93\end{array}$ & $\begin{array}{c}761798 \\
72,38\end{array}$ & $\begin{array}{c}7985 \\
987, \\
82\end{array}$ & $\begin{array}{l}2415 \\
0,07\end{array}$ \\
\hline
\end{tabular}
PRICES

\begin{tabular}{|c|c|c|c|c|c|c|}
\hline \multirow{4}{*}{} & \multicolumn{6}{|c|}{ Chevron Corporation } \\
\cline { 2 - 7 } & $\begin{array}{c}\text { EPS, } \$ \\
\text { per } \\
\text { share } \\
(\mathrm{X})\end{array}$ & $\begin{array}{c}\text { The } \\
\text { price } \\
\text { per } \\
\text { barrel, } \\
\$(\mathrm{Y})\end{array}$ & $\mathrm{X}^{2}$ & $\mathrm{Y}^{2}$ & $\mathrm{X}^{*} \mathrm{Y}$ & $\mathrm{Y}^{\prime}$ \\
\hline 2008 & 11,74 & 97,70 & 137,83 & 9545,2 & 1147 & 103, \\
\hline
\end{tabular}

\section{Field correlation of Chevron Corporation}

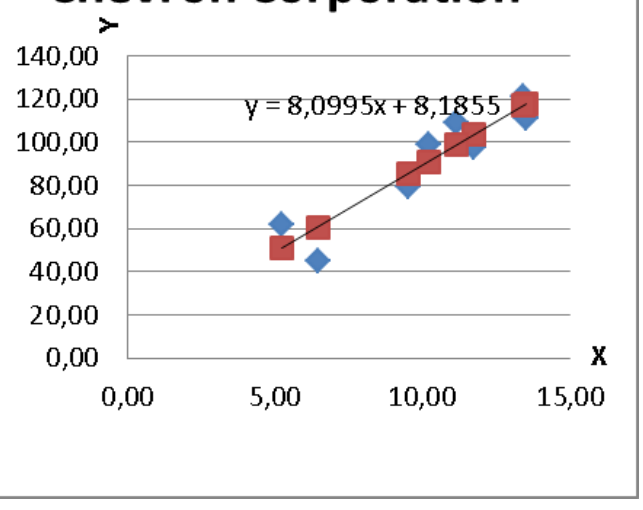

Fig. 1. The field correlation Chevron Corporation 
As for the correlation coefficient, the company Chevron Corporation it is $\mathrm{r}=0.929$; It is indicating a very high connection between these symptoms. While the company "Lukoil" is only $r=0,421$ - from this we can conclude that a reasonable bond. Also, differences due to the company can be traced graphically via the location of points on the graph in relation to the line.

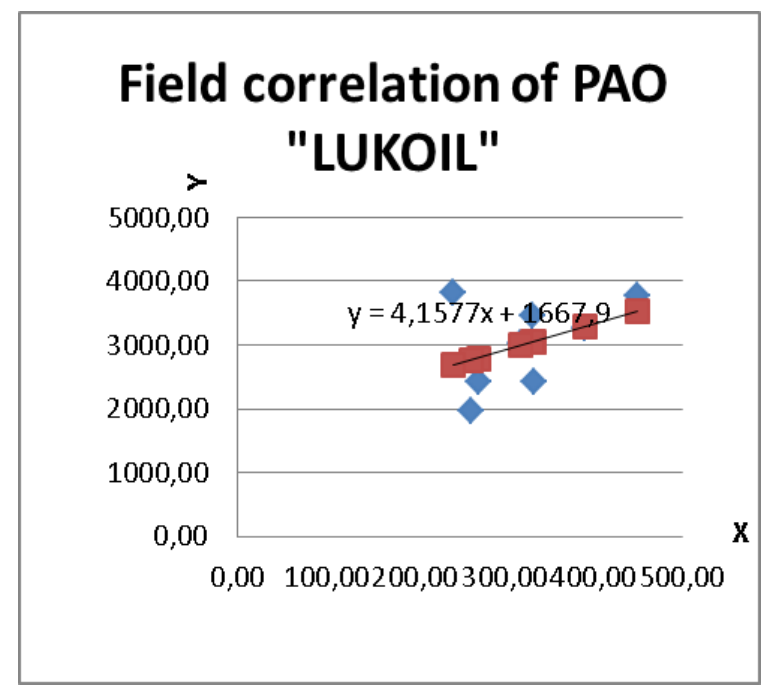

Fig. 2. The field correlation PAO "Lukoil"

\section{CONCLUSION}

Thus, the rate of EPS of largely sensitive to changes in the price of a barrel of oil in the US company in the Russian practice, the sensitivity of a little less strong. This trend is repeated year after year, without exception. There is a direct relationship, when the price per barrel of growth and increasing earnings per share. Accordingly, the market price of oil by the "dictates" the investment attractiveness and effectiveness of the company's oil and gas industry. First of all, it will be expressed in the stability of that future profit per one ordinary share.

Different groups of users of financial statements (which both investors and managers, and so forth.) Interested in assessing the quality of profits, and to this end shall analyse the components of the received financial result, its contribution to the formation of revenues and expenses from ordinary activities and other income. However, with US companies, without going into detail reporting, surely you can not be sure, because generally accepted accounting principles (GAAP) allow you to include in income one-time event (for example, sales of units) that can significantly affect the profit margins and skew EPS. Therefore, the United States decided to disclose the figure most EPS, which includes one-off income and expenses.

One approach to the planning of compensatory measures in adverse trends in the oil markets is the establishment of a reserve of profit as a "safety cushion" when in favourable districts with high rates of profit, the profit is reserved to compensate for its drop in unfavourable periods. In general, for companies forecasting changes in the valuation of the company, depending on external factors important in view of the depth correlation allows advance planning measures to compensate for this adverse effect.

\section{ACKNOWLEDGMENT}

This work funded within the framework of realization of Strategic Programme on National Research Tomsk Polytechnic University Competitiveness Enhancement in the Group of Top Level World Research and Academic Institutions and supported by Russian Foundation for Humanities (RFH) in the frame of the project for scientific studies (Modeling of conditions of the consolidation of tax liabilities to mitigate the conflict of interest of the state and taxpayers), project No. 15-32-01341.

\section{REFERENCES}

[1] K.A.Bannova, I.N.Dolgih, A.B.Zhdanova, N.V. Pokrovskaya, "Developing The Competitive Advantage Of Companies And Regions By The Creation Of Consolidated Groups Of Taxpayers", IBIMA, 2015, pp. 834-841.

[2] N.E. Aktaev, K.A. Bannova, A.S. Balandina, I.N. Dolgih, N.V Pokrovskaia, U.A. Rumina, A.B. Zhdanova, K.N. Akhmadeev, "Optimization Criteria For Entry Into The Consolidated Group Of Taxpayers In Order To Create An Effective Tax Mechanism And Improve The Social, Economic Development Of Regions In The Russian Federation", Procedia - Social and Behavioral Sciences, vol.166, 2015, pp. 30-35.

[3] A. V. Khaperskaya, K. A. Bannova, S. Z. Musina, "The Influence of Corporate Social Responsibility Program on the Economic Mechanism as a Whole", ICEM, 2015, pp. 390-393.

[4] E. N. Dyrina, K. A. Bannova, "Improvement in implementation of fiscal policy of Russia", Procedia - Social and Behavioral Sciences, vol. 166, 2015, pp.58-61.

[5] U. A. Rumina, A. S. Balandina, K. A. Bannova, "Evaluating the effectiveness of tax incentives in order to create a modern tax mechanism innovation development", Procedia - Social and Behavioral Sciences, vol. 166, 2015, pp. 156-160.

[6] I. N. Dolgih, A. B.Zhdanova, K. A. Bannova, "The influence of taxation on small enterprise development in Russia", Procedia - Social and Behavioral Sciences, vol. 166, 2015, pp.216-221

[7] K.A.Bannova, Ju.A. Ryumina, A.S. Balandina, N.V. Pokrovskaia "Consolidated taxation of corporations", Tomsk : STT, 2015, 190 p.

[8] A. Pogorletskiy, and F.Söllner, "The Russian tax system and its international competitiveness", Intereconomics, vol.43, Issue 5, 2008 , pp.288-297.

[9] I. Mayburov, Y. Leontyeva, "Transport tax in Russia as a promising tool for the reduction of airborne emissions and the development of the road network", WIT Transactions on Ecology and the Environment, 2015.

[10] V. Ivanov, V. Mishchenko, and O. Maliutin, "International experience of inflation targeting: model of success for Ukraine", Actual Problems of Economics, vol. 166, № 4, 2015, pp. 414-425.

[11] JONATHAN R. KESSELMAN, "Taxpayer Behavior and the Design of a Credit Income Tax", Income-Tested Transfer Programs, 1982, pp. 215-290.

[12] GCPL consolidated net up $2 \%$ on higher tax, operating expenditure // Focus on Surfactants, vol. 2013, Issue 12, 2013, pp. 7

[13] Carmen Comaniciu , Liliana Bunescu " Taxation in Romania - Some Positive Aspects", Procedia Economics and Finance, vol. 6, 2013, pp.615-620. 
[14] "Asian Paints consolidated net profit for the quarter increases by $11.8 \%$ " Focus on Powder Coatings, vol. 2015, Issue 3, 2015, pp. 2

[15] Aziz Jaafar', John Thornton, “ Tax Havens and Effective Tax Rates: An Analysis of Private versus Public European Firms", The International Journal of Accounting, vol. 50, Issue 4, 2015, pp. 435-457.

[16] "Asian Paints consolidated net sales for 2Q 2010 increases by $16.8 \%$ ", Focus on Powder Coatings, vol. 2010, Issue 2, 2010, pp. 5

[17] Don Herrmann, Tatsuo Inoue, Wayne B Thomas “ PREDICTING CONSOLIDATED EARNINGS IN JAPAN: THE INCREMENTAL USEFULNESS OF SUBSIDIARY EARNINGS", Advances in International Accounting, vol. 16, 2003, pp. 85-103

[18] Qingyue Meng, Hai Fang, $\mathrm{PhD}^{\mathrm{a}}$, Xiaoyun Liu, Beibei Yuan, Jin Xu, "Consolidating the social health insurance schemes in China: towards an equitable and efficient health system", THE LANCET, Vol. 386, Issue 10002, 2015, pp. 1484-1499.
[19] I.S. Antonova, O.A. Negodina, D.D. Vavilov, "Russian company town: creteria and diversification results", IBIMA, 2015, pp. 2181-2187

[20] N. Chistyakova, V. Spitsin, T. Gromova, N. Shabaldina, A. Dudnikova, "Comparative Investment Analysis of Industries Development in Russia and Germany". Proceedings of the 2015 International Conference on Education Reform and Modern Management, Atlantis Press; 2015; Available from: http://dx.doi.org/10.2991/ermm-15.2015.98

[21] I.E. Nikulina, A.A. Tarabanovsky "Monitoring Analysis" and "monitorcriteria" in the system of financial planning of the Autonomous Educational Institution of Higher Professional Education", Fundamental Research, 2009, № 1, pp. 82-88.

[22] I. P. Nuzhina, O. B. Yudakhina, E. I. Kotik , E. G. Matyugina "Ecologization of Management Functions as a Factor of Sustainable Development of Construction Industry in Russia”, ICEM2015, 2015, pp. 414-417 